\title{
THE AFFECTS FROM THE FINANCIAL CRISIS OVER THE AGRO ECONOMY IN DEVELOPED AND DEVELOPING COUNTRIES (WITH REVIEW FOR REPUBLIC OF MACEDONIA)
}

\author{
Dushko Josheski, “Goce Delcev University”, Stip, Republic of Macedonia \\ Marija Gogova, “Goce Delcev University”, Stip, Republic of Macedonia
}

\section{Abstract}

The aim of this paper is to examine current macroeconomic thought about economic and financial crisis. Since 1960's two schools of thought are pre-dominant in macroeconomics Keynesian and neo-classical. Many authors from neo-classical economists such as Robert Lucas (1976), gave a critique to macroeconomic policy and characterize the existing macroeconomic models that relied upon historical aggregate data to design macroeconomic policy as useless. They couldn't help to design a macroeconomic policy. Many authors point out on crisis as all bad things that could happen to good investors. Asymmetric information's create agency problems between investors and firms. Asymmetric information's can distort efficient investment choices (investors may choose less efficient projects). These may also, as a consequence increase monitoring costs, for the investors. This will also reduce netwelfare. Perhaps the paradox of developing countries, and industrialized economies commonly subsidize agriculture is the question that raised the most attention in this regard. Existing view in the macroeconomics is that more attention should be given on deviations from an established path of agricultural protectionism. In the past period over the years eloquent pleas were written by the agricultural economists for less government intervention in agricultural markets. While their arguments are persuasive, the demand for government intervention expressed through the political process remains strong. However, in conclusion on this part as a task of new agroeconomists is to look for new policy directions.

Key words: asymmetrical information, financial crisis, agro economy, agro economy structure in Macedonia 
the first big recession in the new era of globalization (Stiglitz, 2009). For years it has been clear that America's growth have been unsustainable. It was based on a real estate bubble which sustained a consumption boom. The likelihood that there was a bubble was increasingly clear; and the more housing prices grew; the greater likelihood that the eventual crash would be disastrous ${ }^{(2)}$. For Paul Krugman, these crises show how bad things can happen to good economies. During early 1990's, many emerging economies opened their markets for foreign investors ${ }^{(3)}$. Fixed exchange rates stabilized currencies. Privatisation and trade liberalisation transformed stagnant economies. However, Krugman states that huge capital inflows created overvalued currencies. Also they created widening trade deficits. Currency crises back than ended up with devaluation and recession. Hedge funds attacked shaky currencies. IMF proposed tight monetary and fiscal policies. Krugman states that there were no good solutions.

Financial markets reflect the outlook for future economic performance. When a country experiences recession, its stock price will go down and currency will depreciate $(\mathrm{Wu}, 2000)$. When firms and investors are perfectly informed, financial markets function efficiently (Romer, 2000). Asymmetric information's create agency problems between investors and firms. Asymmetric information's can distort efficient investment choices (investors may choose less efficient projects). These may also, as a consequence increase monitoring costs, for the investors. This will also reduce netwelfare. The distortions created in market economy will be long lasting. Matters are even worse in financial markets, as firms in some developed countries receive hundreds of billions of dollars of assistance, well beyond the GDP of poorer countries(Stiglitz,2009).

Pro-cyclical fiscal and monetary policies were often foisted on developing countries, while developed countries followed counter-cycle policies. The problem of dynamic inconsistency has been subject to mainly theoretical research, since Kydland and Prescott (1977) first showed that optimal macroeconomic policies could well be dynamically inconsistent (Blanchard, Fisher, 2003). One example is that tax rates are optimal, because they are expected by the tax payers. But since capital is given fixed, its supply is inelastic, and the government acting to optimize welfare of the individual will tax capital more heavily. Monetary authority (CB), can always impose a lumpsum tax by discretely increasing the money supply, and once the private sector has formed expectations, is tempted to do so. Irresponsible fiscal policy also, makes it more difficult for monetary authorities to pursue price stability (Mishkin, 2000).

Also according to Mishkin as prescription to policy-makers a nominal anchor should be adopted, this is something on which he criticized FED long before crisis in 2008.Also he criticized U.S. government for not accepting price stability as overriding goal. Next, financial markets should allocate capital and manage risks. U.S. financial market did neither of both. American banks mismanaged risk on a colossal scale, with global consequences. (Stiglitz, 2009). Neo-classical models argued that globalization

\footnotetext{
1 During the Great Depression of the 1930s world economic activity collapsed and developing countries found themselves shut out of industrial country export markets by a wall of protection

${ }^{2}$ Alan Greenspan may have been right that you could not be sure that there was a bubble until after it broke, but policy-makers are supposed to make decisions based on the analysis of risk

${ }^{3}$ Countries such as Mexico and Argentina shed their traditional image as high-risk destinations through a wave of reforms.
} 
inevitably led to more stability. Even before this crisis, there was mounting evidence to the contrary.Markets are not self-adjusting, at least in the relevant time frame. Also regulation is inefficient, because there is a time-lag between policy action and effect in the real economy. In the natural rate theory, new classical macroeconomists have assumed that price and wage setters care only about relative wages or prices, and therefore wage and price setting will fully incorporate inflationary expectations. This behavior yields a long-run neutrality result with severe limits on the ability of monetary and fiscal policy (Akerlof, 2001). In the 1980's appeared many agricultural economist and others concerned with agricultural food and sector issues.

Perhaps the paradox of developing countries, and industrialized economies commonly subsidize agriculture is the question that raised the most attention in this regard (Lee, 1989). The question that authors ask themselves is: what can economics in general (political economics), can contribute towards the explanation of farm economics?

First of all, conventional view in economic science is that macroeconomic shocks can impact agriculture strongly than factors that affect the sector directly. The key macro links are exchange rate, consumer income, and interest rate. Shift in these variables (caused by the financial crisis), have in turn induced changes in countries' agricultural prices, production, and consumption and trade (Shane, Liefert, 2000).

Existing view in the macroeconomics is that more attention should be given on deviations from an established path of agricultural protectionism. That analysis will also must include political not just economic factors. Next, the issue of agricultural policy is directed towards a diverse set of goals, thus it is not surprise that policies are inconsistent sometimes (Kramer, 2001).During the periods before crisis usually countries that suffer from depression are experiencing extraordinary growth, one example is that before Asian crisis, Asian economies Korea, Thailand, Malaysia, and Indonesia, had average annual growth rate of GDP of $8.9 \%, 9.5 \%, 7.7 \%$, and $7.6 \%$ respectively.

However rapid growth was fueled by the increases mainly by the increases of inputs used in the production (mainly capital and labor) rather than a rise in productivity. That meant that large capital investment was accompanied by the low levels of productivity (marginal productivity) of capital. This was jeopardizing growth, and chances of investors to earn high (sufficient) returns to pay the loans that funded their investment. In the crisis period trade with agricultural products of countries in the middle of crisis (Thailand, Korea, Indonesia, Russia, Brazil), was decreasing exports and imports were falling ${ }^{(4)}$. This was followed by an appropriate fail in macroeconomic variables.GDP growth in the above mentioned countries failed by $-1.9 \%$ in Brazil and $-13.5 \%$ in Indonesia respectively.

Also in the period of crisis exchange rate is usually defended, but once countries stopped defending the exchange rates, capital flight caused a major depreciation in their currencies. Currency depreciation led to a rise in domestic prices for tradable goods, which led economy to high wide inflation. Capital flight also caused real GDP to fall .The GDP decline for countries in their first year of crisis has ranged from $2 \%$ in Brazil to 14\% in Indonesia (Shane, Liefert, 2000).

In the past period over the years eloquent pleas were written by the agricultural economists for less government intervention in agricultural markets. While their

\footnotetext{
${ }^{4}$ In Thailand, imports of agricultural reported fall by $-1.3 \%$, imports in that period were rising by only $2.4 \%$,Russia imports of agricultural products failed by 48 percentage points, and Russian GDP growth failed by $-4.6 \%$, while in Indonesia imports and exports of agricultural products failed respectively by $-18.2 \%$ i.e. by $-9.7 \%$.
} 
arguments are persuasive, the demand for government intervention expressed through the political process remains strong (Kramer, 1986). However, in conclusion on this part as a task of new agro-economists is to look for new policy directions. In a view of rapid changes taking place in world economy and agriculture, there will be demand for agricultural economics research on policy reform.

The connection of this analysis with Macedonian situations is labored because Macedonia is not the country which innovate policies, usually it's a country which follow already existing strategies from the others developed economies.

In the height of the currently financial crisis, when she shows the imbalance in world-globe frames, Macedonian economy doesn't undervalue the power of agricultural sector.

Especially, fronted, from aspect that become a word about economy witch is involve in developing countries, and country with a lot of natural potential, the governance realized how powerful this agricultural sector is.

From aspect of the finance - the agricultural sector is completed and stimulated, but that doesn't mean that the agro economy is effective.

There are institutions which cover the agricultural work, as: the Government; Ministry of agriculture; Foundation of farmers; Agency for financial support in the agriculture and in the rural development; decentralized activities as a local economic development and offices for rural development.

Very important is that conscience exist, specially for the fact that behind success stand practice, theory (education) and what is more important their connection.

In Republic of Macedonia, the Program for supporting of the rural development involve: investments for improvement of the competitiveness and modernization of agricultural economy (involving aqua culture); investments for finishing, processing, storage, packing and marketing (promoting) of agricultural products; investments for rural infrastructure; financial support of promotion activities for develop of rural tourism; investments for improvement of the knowledge and advancement of human potential of the agricultural manufacturers, provision of advisories services and education for managing with agricultural economy; support for organizing and cooperation with product activities; investments for production and using of specific recourses in this sector (Ministry of agriculture). All this costs should be 422.000 .000 denars.

Despite this analysis of the program and her usage, exist a lot of and significant sighs of revolt from the sides of the agriculture sector, especially in the domain of the finance.

For improvement to the hole work in this sector in Macedonia exist official institution and sectors which make internal revision, approval of projects, approval of payments, control, finance, managing with human resources, informatics and communications technologies structures, sectors for direct payments etc. But, apparently is that the communications and the connections between the official institutions and the labor force have a gap.

In the countries as Macedonia even without conditions of the financial crisis (and even more when conditions and environment are with crisis) must exist careful approach to the financing and subvention and improvement for the agricultural sector. Maybe, that should be the most thoroughly aspect because the export capacity of this country lay especially on the agriculture.

If in the world frames are followed standards for quality, have diversification of products, and the tradition is underlined, than and Macedonia has to follow that step. 
These steps must be based on real ground with strictly defined uses on that what is properly. All gaps between the theory and practice, and between low and labor force must be minimized.

As a challenge in front of the agricultural sector stay the planning production with which previously will be known the negotiations. Also, must have implementation of international standards for quality (as HACCP). The challenges with this implementation are in something else - this standards imposing bigger product costs, costs for conservation, keeping etc. That is why must be done analysis with which the cost- benefit effect will be calculated.

Parlous situation is that doesn't exist awareness of the whole economic situation. Often are concurred statements as: "we are not in a recession and are not headed into a recession" (Roberson, Roy, 2009). Robertson accentuates the essential of the agro sector in financial recovery and speaks about two kinds of messages that were consistent over the financial presentations that he had heard. Those messages are that agriculture is not in as bad a financial situation as other segment of the economy; and the other is that farmers who benefitted from good crops and good prices in 2007 and 2008 took steps to strengthen their long-term financial situation. These messages may be correct in developed agro economies, but Macedonia has problems with this sector before crisis, so now this aspect is more underlined.

The biggest problems in this sector for this region are the asymmetric information. The wrong selection lay on the same level as the moral hazard. Usually money for short-term items appears to be readily available and money for long-term investments in equipment and land appear to be less available, currently this situation is changed and whole subventions are shorted.

Because of this situation, the whole managing with this sector should be done with involving to all objects and subject which will consider on appropriate vantages, potentiality versus weaknesses and thinness of this region and this agro sector.

\section{References:}

1. Akerloff,A.George (2007), Missing motivation in macroeconomics, American Economic Association, Chicago, IL;

2. Blanchard,O. Fischer,S (1993), Lectures in Macroeconomics, The MIT Press,Cambridge Massachusets,London,England

3. Khatib, Dr. Kassim, (2009), "Economic crisis will weight on 2009 cotton prices", Farm Press, 15.01.2009, p.15

4. Kramer,A.Randal (1986), Reexamining Agricultural Policy: Selected issues and alternatives, American Agricultural Economics Association;

5. Krugman,Paul (2008), The Return of the Depression Economics and crisis, Penguin

6. Lee,R.David (1989), The Political Economy of Agricultural policy: Discussion, American Agricultural Economics Association

7. Liefert,M,William,Shane,D,Mathew (2000), The International financial crisis: Macroeconomic linkages to agriculture, Amer.J.Agr.Econ.82 pp:682-687 
8. Lin, Yifu Justin, (1990), "Collectivization and China's Agricultural Crisis in 1959-1961", Peking University

9. Mishkin, S.Frederic, (1996), "Understanding Financial Crises: a Developing Countries Perspective”, National Bureau of Economics Research

10. Mishkin,S.Frederic, (2000), What Should Central banks do? ; Federal Reserve Bank of St.Louis

11. Pingali, Prabhu, (2006), "Agricultural growth and economic development: a view through the globalization lens", Blackwell Publishing

12. Roberson, Ray, (2009), "Food, farming essential to U.S financial recovery", Southeast Farm Press, 21.01.2009, p.4

13. Romer,David, (1996), Advanced Macroeconomics, A Division of McGraw Hill companies

14. Soros, George, (2008) "The new paradigm for Financial Markets" the credit crises of 2008 and what it means, Public Affairs ${ }^{\text {tm }}$ a member of the Persens Books Group

15. Stiglitz,E.Joseph (2009), The Current Economic Crisis and Lessons for Economic Theory, Eastern Economic Journal (2009) 35, 281-296

16. Wu,Chunchi (2000), International Trade Relations and the Contagious Effects of the Asian Financial Crisis, Review of Pacific Basin Financial Markets and Policies, Vol. 3, No. 3 (2000) 367- 399

17. Агенција за поттикнување на развојот на земјоделството, (2009), „Годишен извештај за работата за 2008 година“

18. Агенција за финансиска поддршка во земјоделството и руралниот развој, (2009) „Програма за финансиска подршка на руралниот развој за 2009 година “, Влада на РМ 